\title{
ПОЛУЧЕНИЕ ЛИНАЛИЛХЛОРИДА
}

Нами разработан метод получения чистых образцов транс- и цис-изомеров 1-хлор-3,7. диметилоктадиена-2,6, важных терпеновых галоидопроизводных - геранил- и нерилхлоридов [ $\left.{ }^{1}\right]$. О получении соответствующего им аллильного изомера - 3-хлор-3,7 диметилоктадиена-1,6 опубликовано несколько работ $\left[{ }^{2-6}\right]$, однако убедительных доказательств химического строения полученных продуктов не приводится, причем физические свойства выделенных образцов сильно расходятся, на что было обращено внимание ранее $\left[{ }^{7}\right]$.

Целью настоящей работы явилась разработка метода получения возможно наиболее чистого образца 3-хлор-3,7-диметилоктадиена-1,6, т. е. линалилхлорида.

Исходным веществом служил линалоол, полученный из кориандрового масла и очищенный борным эфиром [ $\left.{ }^{8}\right]$. Была поставлена серия опытов по получению соответствующего хлорида, действуя на линалоол раз личными реагентами. Результаты проведенных опытов представлены в таблице.

\section{Результаты получения хлоридов}

\begin{tabular}{|c|c|c|c|c|c|c|c|c|c|c|}
\hline \multirow[b]{2}{*}{ 氮 } & \multirow[b]{2}{*}{ 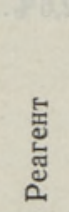 } & \multirow[b]{2}{*}{ Растворитель } & \multicolumn{3}{|c|}{$\begin{array}{c}\text { Состав реакцион- } \\
\text { ной смеси, } 2\end{array}$} & \multirow{2}{*}{ 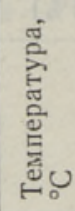 } & \multirow[b]{2}{*}{ 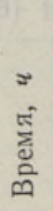 } & \multicolumn{3}{|c|}{ Выход хлоридов, } \\
\hline & & & 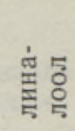 & Ф் & 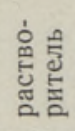 & & & 总 & 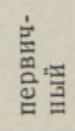 & 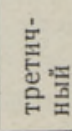 \\
\hline 1 & $\mathrm{HCl}$ & - & 15,4 & 3,5 & - & -5 & 6 & 78,2 & 51,4 & 26,8 \\
\hline 2 & $\mathrm{PCl}_{3}$ & Петролейный эфир & 6,5 & 10 & 50 & -10 & 4 & & 37,0 & 14,8 \\
\hline 3 & $\mathrm{PCl}_{3}$ & Эфир & 7,7 & 5 & 35 & -1 & 6 & 52,7 & 40,1 & 12,6 \\
\hline 4 & $\mathrm{PCl}_{3}$ & Дихлорэтан & 15,4 & 5 & 100 & -10 & 5 & & 42,8 & 22,2 \\
\hline 5 & $\mathrm{PCl}_{3}$ & Петролейный эфир & 23,2 & 10 & 100 & -10 & 6 & 86,2 & 54,7 & 31,5 \\
\hline 6 & $\mathrm{PCl}_{3}$ & То же & 7,5 & 5,0 & 50 & -8 & $6^{*}$ & 78,0 & 46,7 & 31,3 \\
\hline
\end{tabular}

* Реакционную смесь держали при комнатной температуре 72 ч.

Попытка выделения индивидуального линалилхлорида вакуумной ректификацией из смесей, полученных действием хлористого водорода, не дала удовлетворительных результатов, так как были получены основные фракции с содержанием хлоридов всего 43,8-77,0\%. Ректификация полученных действием $\mathrm{PCl}_{3}$ продуктов дала более удовлетворительныє результаты: содержание хлоридов во фракциях составляло $81,2-91,2 \%$. 
Однако в этих выделенных фракциях линалилхлорида содержалось некоторое количество геранилхлорида. Для удаления этого изомера перед ректификацией геранилхлорид был извлечен из смеси хлоридов в виде соединения с уротропином [9]. Из остатка была выделена фракция со следующими свойствами: температура кипения $70^{\circ} \mathrm{C}$ при давлении $5 \mathrm{~ms}$ pт. $c T$., $\quad n_{D}{ }^{20}=1,4660-1,4662, \quad d_{4}^{20}=0,9026$ и содержанием хлорида (эмпирическая формула $\mathrm{C}_{10} \mathrm{H}_{17} \mathrm{Cl}$ ) $94,5 \%$. Приведенные данные довольно близки к константам, характеризующим полученный ранее линалилхлорид изомеризацией геранилхлорида из теломера изопрена с его гидрохлоридами [7].

При определении содержания первичного аллильного хлора в полученном хлориде методом $\left.{ }^{10}\right]$ наблюдался заметный его гидролиз во время титрования в водных растворах. Для устранения гидролиза при определении был разработан модифицированный метод безводного титрования, который, хотя и имеет меньшую точность по отношению к геранилхлориду, вполне применим для определения содержания первичного аллильного хлорида в смесях, где преобладает третичный изомер. При помощи разработанной методики в полученном образце линалилхлорида удалось установить отсутствие первичных аллильных хлоридов. Для доказательства индивидуальности полученное соединение было подвергнуто газохроматографическому анализу. Хро-

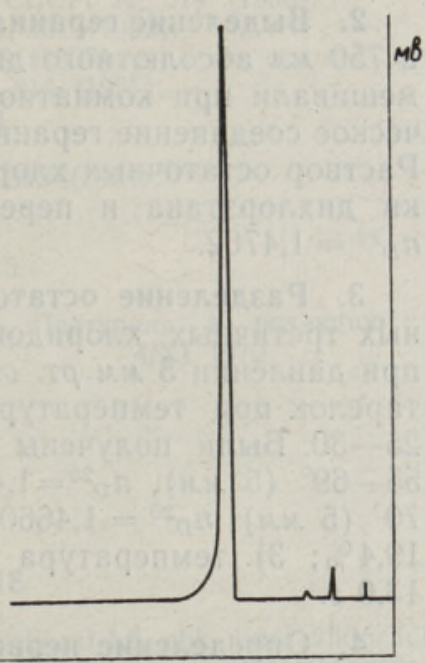

Рис. 1. Хроматограмма линалилхлорида.

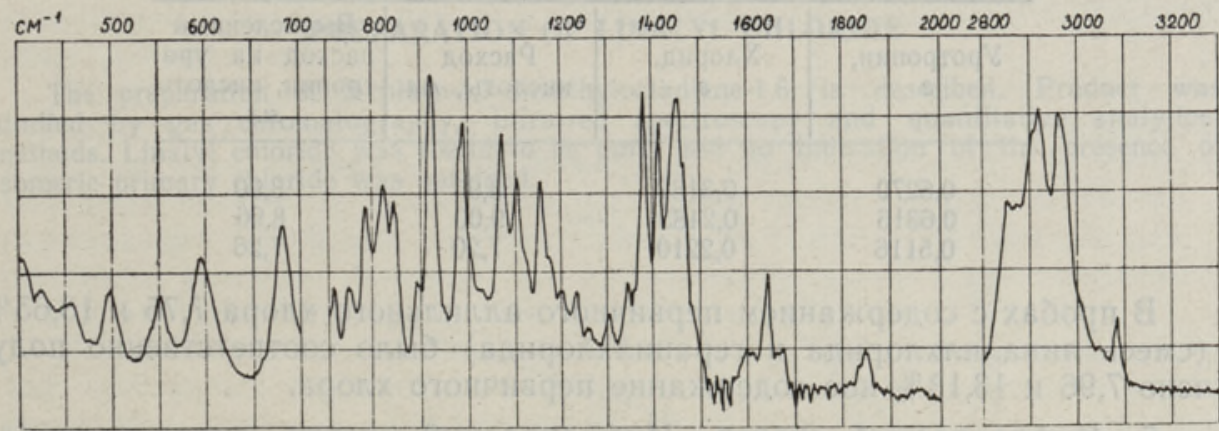

Рис. 2. Инфракрасный спектр линалилхлорида.

матограмма приведена на рис. 1. Для образца был снят инфракрасный спектр (рис. 2), который согласуется со структурой 3-хлор-3,7-диметилоктадиена-1,6.

\section{Экспериментальная часть}

1. Получение хлоридов. К охлажденному до $-12^{\circ}$ раствору линалоола (154 г) в петролейном эфире $(200$ г) добавляли при интенсивном перемешивании 50 г $\mathrm{PCl}_{3}$ с такой скоростью, чтобы температура реак- 
ционной смеси не превышала $-10^{\circ}$. После добавления $\mathrm{PCl}_{3}$ перемешивание продолжалось 4 ч с повышением температуры реакционной смеси до комнатной. Реакционную смесь промывали ледяным раствором карбоната натрия и высушивали над безводным сульфатом магния. Петролейный эфир перегоняли под уменьшенным давлением, и в остатке $(176,5$ г) определяли общее содержание хлора $(17,8 \%)$ и первичного аллильного хлора $(12,0 \%)$. Выход хлоридов $88,4 \%$ от теоретического, в том числе геранилхлорида 59,7 и третичных хлоридов 28,7\%.

2. Выделение геранилхлорида. Синтезированные хлориды растворяли в 750 м абсолютного дихлорэтана, добавляли 87 г уротропина и перемешивали при комнатной температуре 22 . Выделившееся кристаллическое соединение геранилхлорида с уротропином было извлечено водой. Раствор остаточных хлоридов в дихлорэтане высушивался. После отгонки дихлорэтана и перегонки в вакууме получали 49,5 г хлоридов c $n_{D}{ }^{20}=1,4702$.

3. Разделение остаточных хлоридов ректификацией. 120 г остаточных третичных хлоридов подвергались фракционированной перегонке при давлении 5 мм рт. ст. на колонке эффективностью 35 теоретических тарелок при температуре обогрева куба $100-120^{\circ}$ и флегмовом числе 25-30. Были получены следующие фракции: 1) температура кипения $55-69^{\circ}(5$ мм $), n_{D}{ }^{20}=1,4792-1,4657 ; 31,3$ г; 2) линалилхлорид, т. кип. 70 ' $(5$ мм $), n_{D}{ }^{20}=1,4660-1,4662, d_{4}{ }^{20}=0,9026 ; \quad 40,3$ г. Содержание C1 $19,4 \% ; 3)$ температура кипения $71-77^{\circ}$ (5 мм), $n_{D^{20}}=1,4665-1,4718$; 13,0 2.

4. Определение первичного аллильного хлора. Смесь определяемого хлорида, уротропина, иодистого калия и ацетона в колбе перемешивали 3 ч при комнатной температуре [10]. Затем прибавляли 5 мл ледяной уксусной кислоты и титровали потенциометрически с 0,5 н. раствором трихлоруксусной кислоты. Данные титрования линалилхлорида следующие:

\begin{tabular}{|c|c|c|c|}
\hline$\underset{2}{\text { Уротропин, }}$ & $\begin{array}{c}\text { Хлорид, } \\
2\end{array}$ & $\begin{array}{c}\text { Расход } \\
\text { кислоты, } \mu \Omega\end{array}$ & $\begin{array}{c}\text { Вычисленный } \\
\text { расход на уро- } \\
\text { тропин, кислоть } \\
\text { м. }\end{array}$ \\
\hline $\begin{array}{l}0,6270 \\
0,6316 \\
0,5116\end{array}$ & $\begin{array}{l}0,3132 \\
0,2483 \\
0,2210\end{array}$ & $\begin{array}{l}8,95 \\
9,00 \\
7,20\end{array}$ & $\begin{array}{l}8,90 \\
8,96 \\
7,26\end{array}$ \\
\hline
\end{tabular}

В пробах с содержанием первичного аллильного хлора 7,75 и $13,65 \%$ (смесь линалилхлорида и геранилхлорида) было соответственно получено 7,96 и 13,13\%-ное содержание первичного хлора.

5. Инфракрасный спектр. Инфракрасный спектр линалилхлорида (рис. 2) измерялся на приборе UR-10. В спектре присутствуют максимумы поглощения в областях $825-845 \mathrm{~cm}^{-1}$ и $1665-1675 \mathrm{~cm}^{-1}$, характерные для изопропилиденовой группы и трехзамещенной тройной свя зи, и $675 с м^{-1}$, характерный для хлора. Максимумы 925, 990, 1415, $1645 \mathrm{~cm}^{-1}$ характерны винильной группе. Отсутствует максимум геранилхлорида $1255 \mathrm{~cm}^{-1}\left[{ }^{11}\right]$.

\section{Выводы}

1. Разработан метод получения чистого 3-хлор-3,7-диметилоктадиена-1,6, т. е. линалилхлорида из линалоола. 
2. Чистота и химическое строение изготовленного образца установлено с применением химических, газохроматографических и спектральных методов анализа.

\section{Л И ТЕРА Т У Р А}

1. Л ээ т С К., Т ен г С., Изв. АН ЭССР, Хим. Геол., 16, 292 (1967).

2. Пигулев в кий Г. В., Т роян Г. Б., Докл. АН СССР, 72, 519 (1950).

3. Пи гуле в с и й Г. В., Изв. АН СССР, Сер. физ., 14, 401 (1950).

4. В анин И. И., Чер ноя ров а А. А., ЖОХ, 7, 885 (1937).

5. Пи гулев ский Г. В., Бакина Л. А., ЖОХ, 27, 816 (1957).

6. Пигулев в кий Г. В. и др., ЖПХ, 32, 2367 (1959).

7. Л э э т с К., ЖОХ, 28, 3096 (1958).

8. Ш у м йко А. К. и др., Авт. свид. № 99224 и 100393 (1954).

9. Л э э т с К. и др., ЖОХ, 27, 1510 (1957).

10. Л э э т с К. и др., ЖОХ, 27, 2969 (1957).

11. B a r n a rd D., B at e ma n L., J. Chem. Soc., 1950, 915.
Ннститут химии
Академии наук Эстонской ССР
Поступила в редакцию 4/XI 1970

\section{SIGNE TENG, K. LAATS}

\section{LINALUOLKLORIIDI SAAMINE}

Esitatakse uus meetod puhta 3-kloor-3,7-dimetüüloktadieeni-1,6 ehk linalüülkloriidi saamiseks linaloolist. Produkti individuaalsust kontrolliti keemiliste, gaasikromatograafiliste ja spektraalmeetoditega.

SIGNE TENG, K. LÄATS

\section{PREPARATION OF LINALYL CHLORIDE}

The preparation of 3-chloro-3,7-dimethyloctadiene-1,6 is described. Product was studied by gas chromatography, infra-red spectroscopy and quantitative analytical methods. Linalyl chloride was found to be pure, and no indication of the presence of isomeric primary chloride was obtained. 